\title{
RANCANG BANGUN ALAT PENYORTIR TINGKAT KEMATANGAN MANGGA GEDONG GINCU MENGGUNAKAN MIKROKONTROLER DAN SENSOR WARNA TCS 3200
}

\author{
Asep Rachmat ${ }^{1)}$ Ardi Mardiana ${ }^{2)}$ Iis Caswini ${ }^{3)}$ \\ Program Studi Teknik Mesin, Fakultas Teknik, Universitas Majalengka \\ E-mail : asep18rachmat75@gmail.com \\ Program Studi Informatika, Fakultas Teknik, Universitas Majalengka \\ E-mail : aim@ftunma.ac.id \\ Program Studi Informatika, Fakultas Teknik, Universitas Majalengka \\ E-mail : Iis.caswini@gmail.com
}

\begin{abstract}
Industry has started using technological advancements both in control and speed and automatic systems. Utilization of technology one of them on fruit sorting process. The sorting process is very important to maintain the quality of the fruit. In making the sorter required method of system development is one of them prototype. Prototype has 5 stages of identification needs pemakaii, make prototype, test, repair and develop product version. Mature gedong maturity sorter has been designed using a microcontroller and color sensor TCS 3200 to distinguish mature and raw color. This tool is composed of TCS 3200 Color Sensor to distinguish color, two servo motors as propulsion, PIR Sensor as counters of mango and LCD as information of number of sorting results. Tests have been done on mango gedong lipstick which amounted to 3 ripe mango and 2 raw mangoes. The results show a positive response for 3 experiments on each sample. Success at the time of detection effect from the outside light and the position of mango when facing the sensor.
\end{abstract}

Keywords : Sorter Tools, Color Sensor TCS 3200

\section{PENDAHULUAN}

Teknologi informasi tidak hanya berkembang pesat pada sektor ekonomi dan perdagangan saja tetapi sektor pertanian juga telah banyak pemanfaatannya, mengingat sektor pertanian ini merupakan mata pencaharian yang dominan dilakukan oleh penduduk indonesia. Sektor pertanian dibidang buah mangga salah satunya yaitu mangga gedong gincu, menurut institut pertanian Bogor (2012) Proses panen mangga gedong gincu akan terlihat dari warna buahnya yang kuning kemerahan (gincu) jika mangga dipetik sebelum warna gincunya keluar maka akan disebut mangga gedong biasa bukan mangga gedong gincu, ukuran mangga gedong gincu untuk kelas A adalah > 250 g dan kelas B 200-250 g. Gedong gincu produksi Kabupaten Majalengka yang termasuk daerah tropis menjadikan pohon mangga gedong gincu tumbuh dengan subur sehingga banyak permintaan pasar.

Dalam Jurnal (Dimas Rizki Radityo, 2012) menurut Novianto, 2009 : Kondisi kematangan dari buah tropis akan sangat terlihat dari warnanya, apakah buah tersebut masih mentah, setengah matang, matang atau sudah busuk. Oleh karena itu ekstraksi ciri warna dari buah tropis akan dapat dimanfaatkan untuk mengetahui tingkat kematangan dari buah tersebut untuk kepentingan industri.

Industri sekarang ini sudah mulai menggunkan kemajuan teknologi baik dalam sistem kontrol maupun pengambilan keputusan salah satunya adalah dibidang telekomunikasi dan elektronika yaitu mikrokontroler. Untuk skala pembelajaran dan industri kecil dapat menggunakan mikrokontroler dalam bentuk modul 
seperti Arduino . Arduino dapat menggabungkan berbagai komponen inputdan output. Ekstraksi ciri warna dapat digunakan untuk membuat sistem penyortiran berbasis mikrokontroler dengan memanfaatkan sensor warna sebagai input sistem.

Sensor warna TCS 3200 adalah sensor warna yang sering digunakan pada aplikasi mikrokontroler untuk pendeteksian suatu object benda atau warna dari objet yang di monitor. Sensor warna TCS 3200 juga dapat digunakan sebagi sensor gerak, dimana sensor mendeteksi gerakan suatu object berdasarkan perubahan warna yang diterima oleh sensor. (Dasar, 2012)

Dalam menangani pasca panen yang banyak mangga gedong gincu salah satu masalah yang terjadi adalah kurangnya kualitas dalam menyortir buah manga gedong gincu yang matang dan mentah dalam proses pernyortiran dan perhitungan masih menggunakan tenaga manusia.

\section{TINJAUAN PUSTAKA}

\section{Arduino Uno R3}

Arduino Uno R3 adalah papan elektronik (elektrik board) open source yang mempunyai masukan dan keluaran serta terdapat komponen utama untuk mengendali program yang bisa ditulis dan dihapus dengan cara khusus. Struktur serta antarmuka Arduino yang sederhana memberi kemudahan pengguna dalam memahami parameter (visualisasi maupun non-visual) seperti konsep sensor atau penerapan sensor elektronik yang tidak selalu bisa diamati langsung seperti sinar infra merah. Konsep bahasa Arduino dengan mentargetkan ke pin tertentu (secara fisik) menjadikannya lebih mudah dipahami oleh berbagai kalangan. (Koswata,

2015)

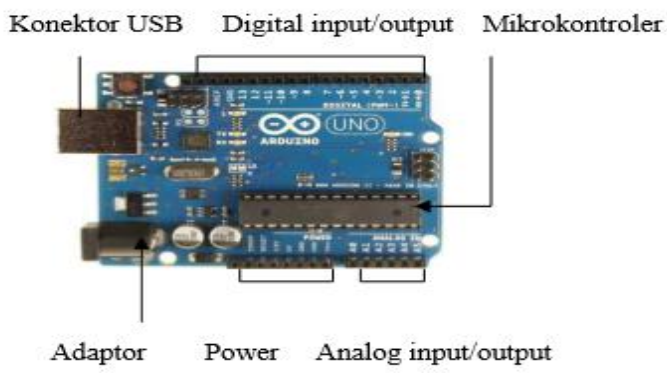

Gambar 1: Arduino Uno R3

\section{Sensor Warna TCS 3200}

Pada dasarnya sensor warna TCS3200 adalah rangkaian photo dioda yang disusun secara matrik array $8 \times 8$ dengan 16 buah konfigurasi photodioda yang berfungsi sebagai filter warna merah, 16 photodioda sebagai filter warna biru dan 16 photodioda lagi tanpa filter warna. Sensor warna TCS3200 merupakan sensor yang dikemas dalam chip DIP 8 pin dengan bagian muka transparan sebagai tempat menerima intensitas cahaya yang berwarna. Pada Gambar 2.2 menunjukkan bentuk fisik sensor warna TCS3200, dan skema pin sensor tersebut. (Stevanus, 2012)
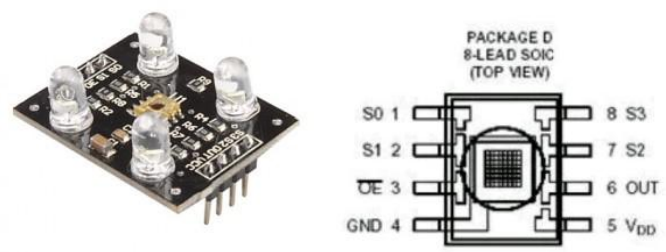

Gambar 2 : Bentuk Fisik dan Skema Sensor

1) Karakteristik Sensor Warna TCS3200

IC TCS230 dapat dioperasikan dengan supply tegangan pada Vdd berkisar antara 2,7Volt $-5,5$ volt, dalam pengoperasiannya sensor tersebut dapat dilakukan dengan dua cara :

a) Dengan mode supply tegangan maksimum, yaitu dengan menyuplai tegangan berkisar antara 2,7volt $-5,5$ volt pada sensor warna TCS230.

b) Mode supply tegangan minimum, yaitu dengan menyuplai tegangan 0 sampai 0,8 .

\section{Motor Servo}

Motor servo adalah sebuah motor dengan sistem umpan balik tertutup dimana posisi dari motor akan diinformasikan kembali ke rangkaian kontrol yang ada di dalam motor servo. Motor ini terdiri dari sebuah motor DC, serangkaian gear, potensiometer dan rangkaian kontrol. Potensiometer berfungsi untuk menentukan batas sudut dari putaran servo. Sedangkan sudut dari sumbu motor servo diatur berdasarkan lebar pulsa yang dikirim melalui 
kaki sinyal dari kabel motor. Pada badan servo tertulis tipe servo yang bersangkutan. Motor servo standar yang kali ini dipakai memiliki 3 buah kabel yaitu, power, ground dan signal. Bentuk dari servo standar seperti pada gambar dibawah ini :

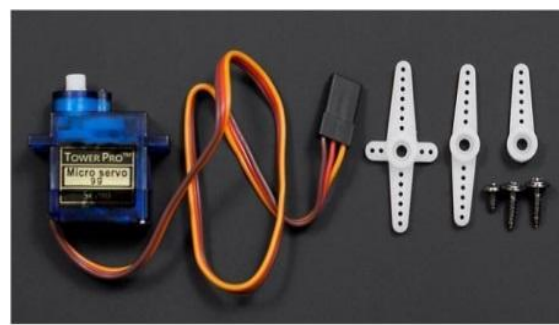

Gambar 3 : Servo Motor Standar

\section{Sensor PIR (Sensor Gerak)}

Sensor merupakan alat yang mampu menangkap fenomena fisik atau kimia dan mengubanya menjadi sinyal elektrik baik arus listrik ataupun tegangan (Deri, Kurniawan, 2011). Fenomena fisik yang mampu menstimulasi sensor untuk menghasilkan sinyal elektrik seperti temperatur, tekanan, gaya, medan magnet cahaya,pergerakan, dan sebagainya. (Purnomo, 2015)

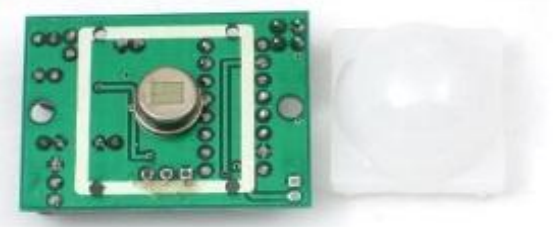

\section{Gambar 4 : Sensor PIR bagian Depan}

Proses kerja sensor ini dilakukan dengan mendeteksi adanya radiasi panas suhu tubuh manusia yang diubah menjadi tegangan. Gambar cara kerja dan blok diagram sensor Passive Infra Red (PIR) dapat dilihat pada gambar dibawah ini :

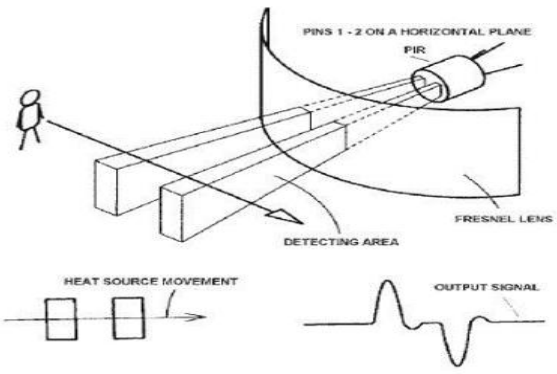

\section{Liquid Crystal Display (LCD)}

Liquid Crystal Display atau biasa kita kenal dengan nama LCD,merupakan adalah suatu jenis media tampilan yang menggunakankristal cair sebagai penampil utama. LCD sudah digunakan di berbagaibidang misalnya dalam alat-alat elektronik seperti televisi, kalkulator ataupun layar komputer. Kini LCD mendominasi jenis tampilan untuk komputer meja maupun notebook karena membutuhkan daya listrik yang rendah, bentuknya tipis, mengeluarkan sedikit panas, dan memiliki resolusi tinggi. Berikut ini merupakan keuntungan jika kita ingin menggunakan tampilan LCD 20 × 4 karakter (Kastawa, 2014):

1) Konsumsi daya rendah

2) Biaya rendah

3) Bentuknya padat dan ringan

4) Panas yang dipancarkan sedikit

5) Penggunaannya mudah

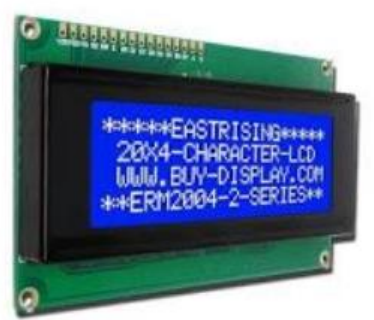

Gambar 6: Liquid crystal display (LCD) 20 x 4

\section{METODE PENELITIAN}

\section{Metode Pengembangan Sistem}

Metode pengembangan sistem yang digunakan untuk membuat pernyortiran tingkat kematangan mangga gedong gincu berdasarkan warna adalah model prototype.

Gambar 5 : Cara Kerja Sensor PIR

Computer Science | Industrial Engineering | Mechanic Engineering | Civil Engineering 


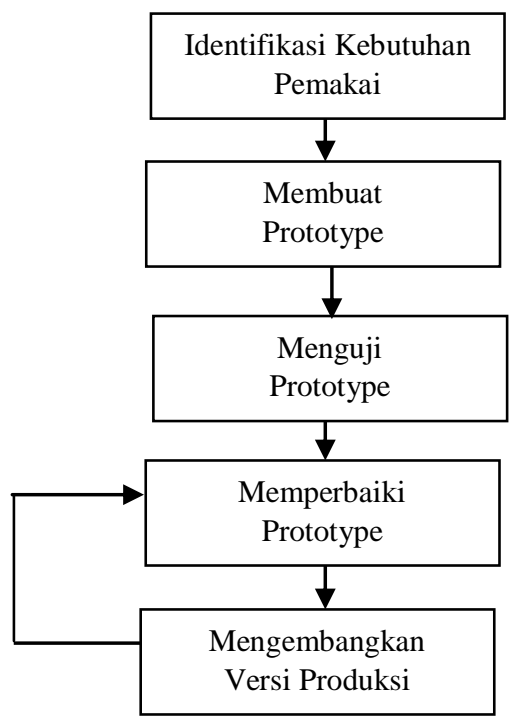

Gambar 7: Alur Penelitian

\section{Perancangan Sistem}

Perancangan sistem ini menjelaskan tentang proses perancangan penyortir tingkat kematangan mangga gedong gincu. Perancangan sistem mempunyai dua tujuan yaitu memenuhi kebutuhan kepada pemakai (user) dan untuk memberikan gambaran yang jelas serta rancang bangun yang lengkap kepada pemrogram (developer) dan ahli teknik lainnya yang terlibat dalam pembuatan sistem.

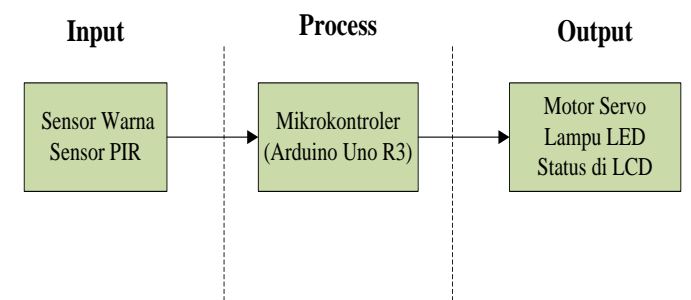

Gambar 8 : Blok Diagram Penyortir Tingkat Kematangan Mangga

Bagian input merupakan input yang digunakan sebagai masukan yang akan mempengaruhi sistem (pertama kali) untuk menghasilkan output (keluaran). Input pada sistem ini adalah :

1. Sensor Warna untuk membaca warna pada objek.

2. Sensor PIR untuk menghitung jumlah mangga yang disortir.

Bagian terakhir dalam sistem ini adalah output. Output merupakan hasil keluaran dari masukan yang sudah diproses oleh bagian pemroses
(mikrokontroler).Output yang didapatkan pada alat penyortir kematangan mangga dengan mikrokontroler Arduino UNO R3 adalah motor servo, LED dan status di LCD.

\section{Perancangan Perangkat Keras (Hardware)}

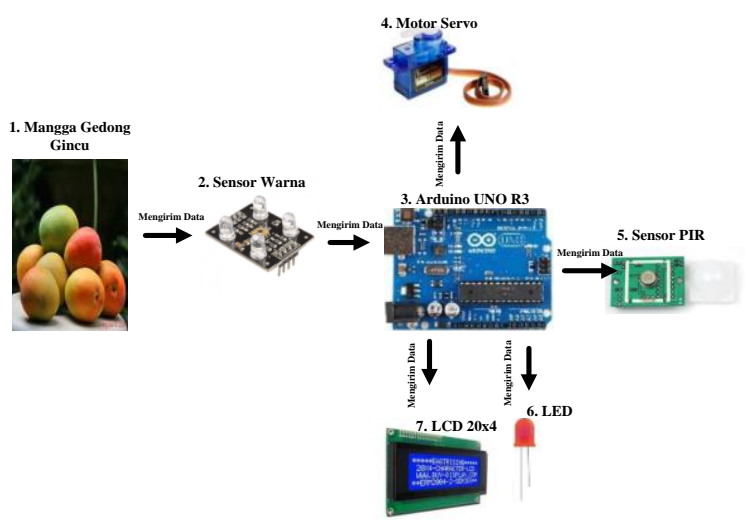

\section{Gambar 9 : Perancangan Perangkat Keras (Hardware)}

Berikut penjelasan dari gambaran arsitektur alat penyortir kematangan mangga :

1) Mangga gedong gincu digunakan sebagai objek untuk melakukan penyortiran terdiri dari 3 mangga gedong gincu yang matang dan 2 mangga gedong gincu yang masih mentah, kualitas B 200-250 gram.

2) Sensor warna membaca warna pada objek (mangga gedong gincu) nilainya berupa RGB untuk melihat kematangan buah mangga gedong gincu, dimana kuning dan merah mewakili kondisi matang, dan hijau mewakili kondisi mentah, untuk menentukan matang atau mentah digunakan range warna untuk masingmasing warna.

3) Arduino UNO R3 digunakan sebagai controller (pengendali) alat penyortir kematangan mangga mulai dari membaca sensor warna, penggerak untuk menahan dengan servo, membaca gerakan menggunakan sensor PIR dan LED, dan juga menampilkan status hasil penyortir menggunakan LCD.

4) Motor servo disini digunakan sebagai output dari hasil pembacaan dari sensor warna yang akan menentukan jalur kemana arah mangga yang matang dan mentah.

5) Sensor PIR digunakan untu mendeteksi gerakan pada jalur yang akan dilewati oleh mangga 
yang akan dideteksi gerakannya dan dihitung berapa banyak mangga yang lewat pada jalur itu dan dihitung secara otomatis oleh sensor PIR tersebut.

6) LED digunakan jika sensor PIR mendeteksi gerakan yang ada maka LED ini akan menyala sebagai tanda bahwa ada mangga yang terdeteksi.

7) LCD digunakan sebagai media informasi mengenai mangga itu matang atau mentah dan jumlah panen yang telah disortir.

\section{Perancangan Perangkat Lunak (Software)}

Pada perancangan perangkat lunak ini akan dibahas mengenai perangkat lunak yang akan dibangun guna menunjang kinerja dari alat pernyortiran kematangan mangga dengan mikrokontroler Arduino UNO R3. Perancangan perangkat lunak pada Arduino UNO R3.

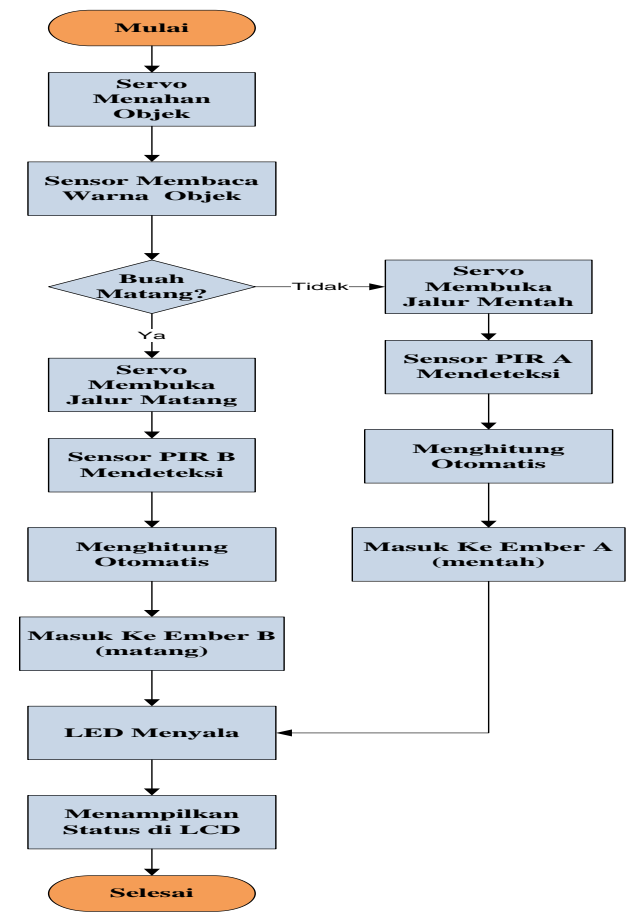

Gambar 10 : Alur Perancangan Perangkat Lunak

IV. PEMBUATAN,

HASIL

DAN PEMBAHASAN

1. Pembuatan Alat Penyortir Kematangan Mangga Gedong Gincu

Pembuatan alat penyortir kematangan mangga akan menjelaskan proses pembuatan alat penyortir terutama penempatan komponen- komponen perangkat keras yang saling terhubung satu sama lain. Berikut ini proses pembuatan alat penyortir, yaitu :

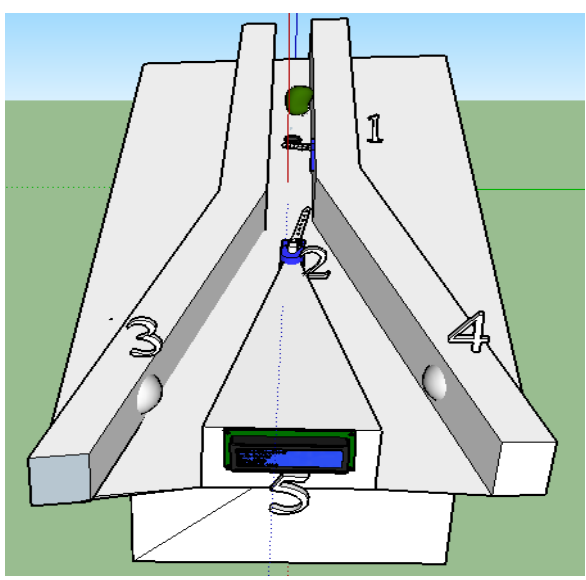

Gambar 11 : Desain Penyortir Mangga

Berikut ini langkah-langkah penggunaan alat penyortir kematangan mangga gedong gincu :

1. Dekatkan mangga gedong gincu ke sensor warna dan akan ditahan oleh servo A untuk menunggu proses pembacaan warna pada objek, sensor warna akan memantulkan cahaya dari LED kepada objek hasil dari pemantulan cahaya akan mendapatkan nilai warna RGB selanjutnya arduino akan memproses nilai tersebut dan motor servo penahan sebagai output yang bertindak sebagai penahan.

2. Setelah selesai proses pembacaan warna pada mangga (objek) maka servo B akan membuka jalur sesuai dengan hasil yang didapatakan, Jika masih mentah maka jalur servo B akan menutup atau memblok ke arah jalur matang dan jika mangga matang maka jalur servo B akan menutup ke arah jalur mentah.

3. Perhitungan otomatis dilakukan oleh sensor PIR A dimana sensor PIR A akan mendeteksi mangga mentah yang bergerak ke arah sensor.

4. Perhitungan otomatis dilakukan oleh sensor PIR B dimana sensor PIR akan mendeteksi mangga matang yang bergerak ke arah sensor.

5. Hasil dari perhitungan yang sudah di deteksi oleh sensor pir akan di proses oleh arduino dan arduino akan memberikan output ke layar LCD (Liquid Crystal Display) untuk menampilkan semua total mangga yang sudah disortir tersebut. 


\section{Hasil dan Pembahasan}

Hasil yang didapatkan setelah melakukan tahap perancangan dan pembuatan adalah sebuah sistem utuh berupa alat penyortir kematangan mangga. Alat penyortir kematangan mangga memiliki kemampuan sebagai berikut:

1) Dapat mendeteksi mangga gedong yang matang dan mentah.

2) Menghitung secara otomatis hasil mangga matang dan mentah yang telah disortir.

3) Hasil dari perhitungan otomatis akan di tampilkan pada LCD

Alat penyortir tingkat kematangan mangga gedong gincu yang sudah dibangun selanjutnya akan dilakukan pengujian dan pembahasan baik itu pengujian perangkat keras maupun keseluruhan sistem. Alat penyortir tingkat kematangan mangga gedong gincu yang sudah dibangun dapat dilihat pada gambar 3.2

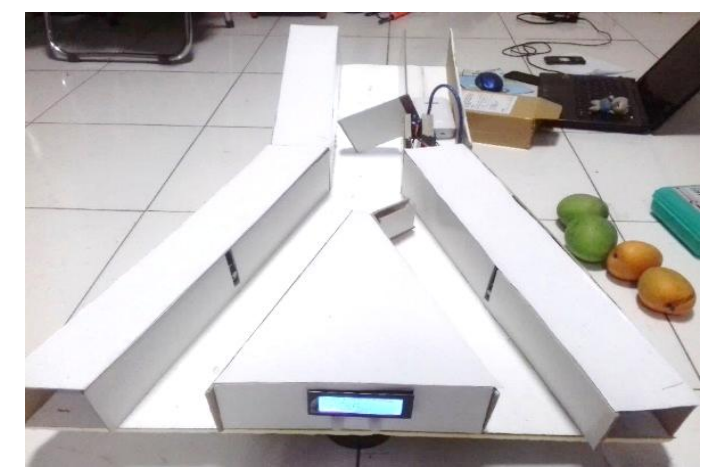

Gambar 12: Alat Penyortir Kematangan Mangga Gedong Gincu

\section{KESIMPULAN}

Alat penyortir ini dapat menyortir atau memisahkan antara mangga mentah dan matang menggunakan sensor warna dengan cara menentukan rata-rata nilai warna pada masingmasing mangga mentah dan matang.

Hasil mangga yang sudah disortir dapat dihitung secara otomatis dengan menggunakan sensor PIR (sensor gerak) mangga yang bergerak melewati senor PIR akan di deteksi oleh sensor dan dihitung, hasil nyah akan ditampilkan di LCD jumlah mangga matang dan mentah.

\section{REFERENSI}

Dasar, E., 2012. Sensor Warna TCS 3200. http://elektronika-dasar.web.id/sensor-warnatcs230/ [Diakses 24 June 2017].

Dimas Rizki Radityo, M. R. F., 2012. Alat Penyortir dan Pengecekan Kematangan Buah Menggunakan Sensor Warna. Jurnal Teknik Komputer, Volume 20 No.2, p. 89.

Kadir, A., 2003. Pengenalan Sistem Informasi. Yogyakarta: s.n.

Kastawa, A., 2015. Sistem Keamanan Komplek Perumahan Berbasis Smartphone. Universitas Komputer, Bandung .

koswata, 2015. Sistem Keamanan Komplek Perumahan Berbasis Smartphone Android. Universitas Komputer.

Stevanus R, K. R., 2012. Aplikasi Sensor Warna RGB TCS 3200. Politeknik Mekatronika Sanata Dharma. 